\title{
Revision of Late Tithonian charophytes from Lisbon and Sintra-Cascais (Portugal): taxonomy, biostratigraphy and palaeobiogeographical significance
}

\author{
RICARDO PEREIRA ${ }^{1,2, *}$, ANA CRISTINA AZERÊDO ${ }^{2} \&$ MONIQUE FEIST $^{3}$ \\ ${ }^{1}$ Partex Oil and Gas, R. Ivone Silva 6, 1st, 1050-124, Lisbon, Portugal and Centro de Geologia, Universidade de Lisboa Campo Grande, \\ Ed. C6 - $4^{\circ}$ Piso, 1749-016, Lisboa, Portugal \\ ${ }^{2}$ Departamento de Geologia and Centro de Geologia, Faculdade de Ciências, Universidade de Lisboa Campo Grande, Ed. C6 - $4^{\circ}$ Piso, \\ 1749-016, Lisboa, Portugal \\ ${ }^{3}$ Laboratoire de Paléontologie, Université Montpellier II Place Eugène Bataillon, F-34095 Montpellier, Cedex 05, France \\ *Corresponding author (e-mail: ricardo.pereira@partex-oilgas.com)
}

\begin{abstract}
The re-evaluation of the charophyte content of 'Purbeckian' sediments from several sections around Lisbon (Olelas and Brouco) and Sintra-Cascais (Murches, Atrozela and MalveiraGuincho) revealed new palaeofloral associations from the Late Tithonian of the South Lusitanian Basin (Portugal). These sections contain Globator rectispirale, G. aff. nurrensis, Nodosoclavator bradleyi, Clavator reidi, Clypeator cf. discordis, Porochara maxima, and newly described occurrences of $P$. jaccardi, Mesochara harrisi and nodosoclavatoroide utricles. These revised data reinforce the evidence for assigning most of the studied deposits to a Late Tithonian age, instead of the formerly accepted wider interval Tithonian to Early Berriasian ('Purbeckian'). Population analysis and statistics were applied in order to better assess population variation of the different species.

The results of this study are relevant as they contribute to improve the biostratigraphical definition of the 'Purbeckian' formations of Portugal and allow more accurate palaeobiogeographical interpretations within the central Tethyan domain, by comparison of the identified charophyte assemblages with documented Jurassic-Cretaceous transition charophytes from other regions. J. Micropalaeontol. 29(1): 37-49, May 2010.
\end{abstract}

KEYWORDS: charophytes, biostratigraphy, palaeobiogeography, Late Tithonian, Portugal

\section{INTRODUCTION}

The present work presents and discusses the results of a re-evaluation study of the charophyte content of several sections (Murches, Malveira-Guincho, Atrozela, Brouco and Olelas; Fig. 1). These belong to the classical sections covering the JurassicCretaceous transition ('Purbeckian' facies) of the Lisbon and Sintra-Cascais regions (southern Lusitanian Basin, west Portugal; Fig. 1), formerly described by Ramalho (1971) and Rey (1972). These floral assemblages were only partially identified and incompletely studied in previous works, which aimed at broader stratigraphical analysis. The charophytes of the Brouco section were partially revised by Feist et al. (1995). Consequently, a comprehensive description of the charophytes occurring in these successions is used to establish a comparison with other regions and biozones. The systematic study of the charophytes presented herein is reinforced by statistical analysis, aiming at a better characterization of the intraspecific population variation. This methodology gives the best results when applied to a population of charophytes with few distinguishing features, such as Characeae and Porocharaceae.

The present study used, with permission of the owners, samples from the Ramalho and Grambast collections, from the archives of the Instituto Geológico e Mineiro (Portugal) and from the University of Montpellier II (France), respectively. Fourteen samples from marly beds of the five selected sections (Murches, Malveira-Guincho, Atrozela, Brouco and Olelas) were studied and described with regard to charophyte content. At the Murches section, a new field survey and sampling of the few exposed marly layers revealed rare and poorly preserved charophytes. However, the overall content of the sample residues was also analysed, including foraminifers (A. Azerêdo) and

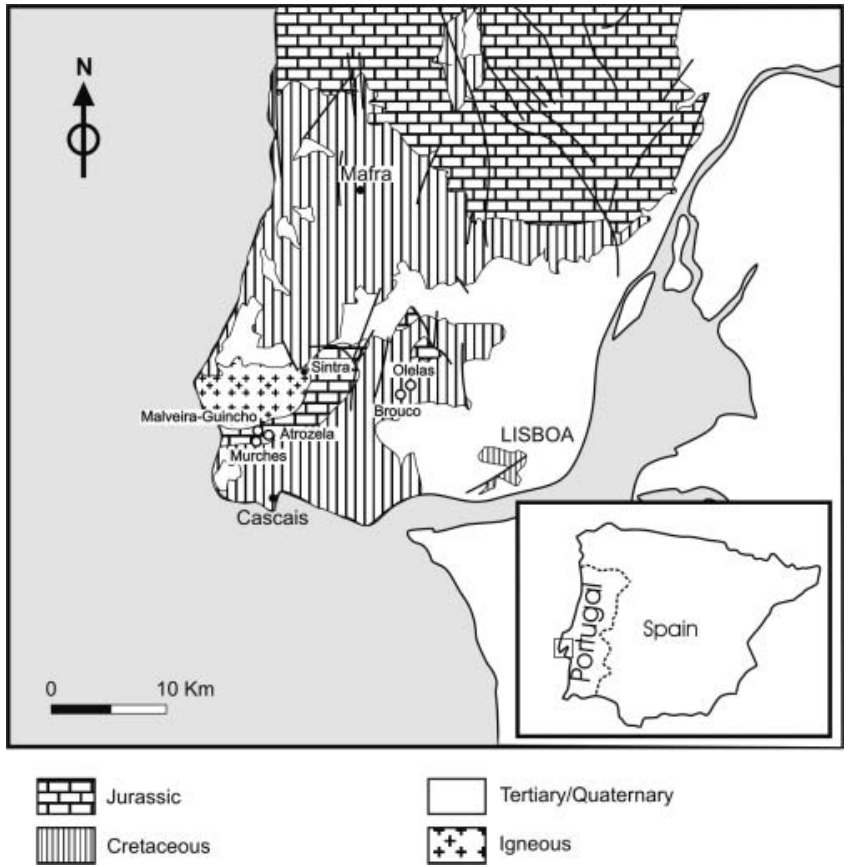

Fig. 1. Schematic location of the studied sections and simplified geological map of the Lisboa and Sintra-Cascais regions (after Pereira \& Cabral, 2005).

ostracods (M. C. Cabral, pers. comm.). This has helped to establish a correlation with the units described by Ramalho (1971) (see below). The Murches section, together with the Malveira-Guincho section, can still be followed approximately 


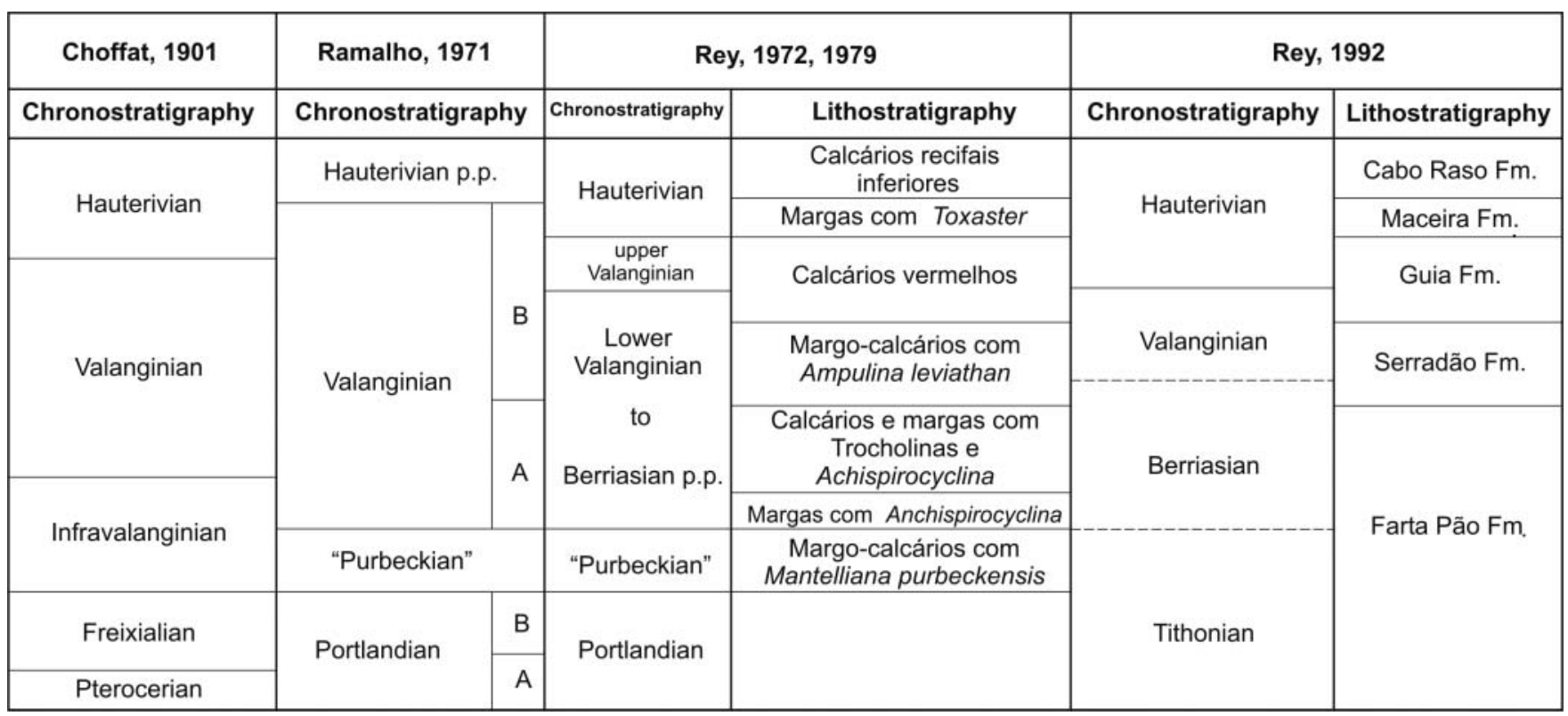

Fig. 2. Comparative chart of the chronostratigraphical and lithostratigraphical units of the Jurassic-Cretaceous transition in the study region, according to the principal previous works (Choffat, 1901; Ramalho, 1971; Rey, 1972, 1979, 1992).

in the field, but with a few gaps. The other three sections are no longer exposed or are very poorly preserved.

In all of the five sections limestone dominates over marl; therefore, the number of levels likely to yield material suitable for charophyte study is restricted. However, the complete Late Jurassic-Early Cretaceous succession is very well documented and clearly established in the study region and at other locations in the basin. Therefore, the interval corresponding to the 'Purbeckian' facies is very well constrained, as addressed below (see Rey et al., 1968; Ramalho, 1971; Rey, 1972, 1992; Ramalho \& Rey, 1975; Ramalho et al., 1981, 1993).

\section{BRIEF GEOLOGICAL SETTING}

The Late Jurassic-Early Cretaceous successions from Lisbon and the Sintra-Cascais regions are part of the sedimentary fill of the Mesozoic Lusitanian Basin of west-central Portugal (Fig. 1), which is one of the marginal basins associated with the opening of the North Atlantic Ocean (e.g. Ribeiro et al., 1979; Wilson et al., 1989). Most of the basin fill is Jurassic in age, but sediments from the Upper Triassic to the Upper Cretaceous occur, with a Tertiary cover. The basin is bounded to the east by uplifted Hercynian basement and to the west (offshore) by small basement horsts. Initial rifting took place during the Late Triassic, followed by mostly non-rift conditions during the Early and Middle Jurassic; the main rifting phase, leading to ocean spreading between Iberia and Newfoundland, led to major subsidence and extension from the Late Jurassic to Early Cretaceous (e.g. Ribeiro et al. 1979; Wilson et al. 1989).

The lithostratigraphical succession of the Lusitanian Basin is bounded at the base by the unconformity between pre-Mesozoic and Triassic formations. The latter correspond to alluvialfluvial deposits, which are succeeded by Lower and Middle Jurassic marine carbonates. The Upper Jurassic and the Cretaceous are composed of diverse marine, terrigenous and mixed facies, reflecting the frequent changes of depositional and tectonic conditions (e.g. Ramalho et al., 1993; Rey et al., 2006).

\section{STRATIGRAPHICAL SETTING}

The charophyte-bearing deposits are part of wider successions that range from the Upper Oxfordian to the Valanginian, comprising a broad range of marine (pelagic/hemipelagic, reefal and lagoonal) and terrestrial-influenced facies.

The uppermost Jurassic-lowermost Cretaceous deposits reflect a regressive trend, evolving from outer-marine to shallowmarine and then to lagoonal-lacustrine settings, with some terrigenous influence. The formations are locally affected by contact metamorphism related to the intrusion of the granitic Sintra Massif. For detailed descriptions of these formations the reader is referred to Ramalho (1971), Rey (1972, 1992), Ramalho \& Rey (1975) and Ramalho et al. (1981, 1993).

Since the pioneering works on the region, the latest Upper Jurassic units have been informally subdivided into 'Calcários com L. pseudoalternicosta', 'Pterocerian' and 'Freixialian' (Choffat, 1901), 'Portlandian A' and 'Portlandian B' (Ramalho, 1971) or Portlandian (Rey, 1972) (Fig. 2). The earliest Cretaceous units were referred to as 'Infravalanginian' (Choffat, 1901), 'Purbeckian' (Ramalho, 1971) or 'Margo-calcários com Mantelliana purbeckensis' (Rey, 1972). Nowadays, these units are formally grouped in the Farta Pão Formation (Rey, 1992; Rey et al., 2006) (Fig. 2).

The present work covers only the lagoonal-lacustrine deposits of the Jurassic-Cretaceous transition, mostly from the interval traditionally known as the 'Purbeckian' (Ramalho, 1971; Rey, 1972; Ramalho \& Rey, 1975). This terminology can be misleading for biostratigraphical purposes and has been adopted differently by several authors. In the study area, this interval has been well constrained by Ramalho (1971), as follows: 


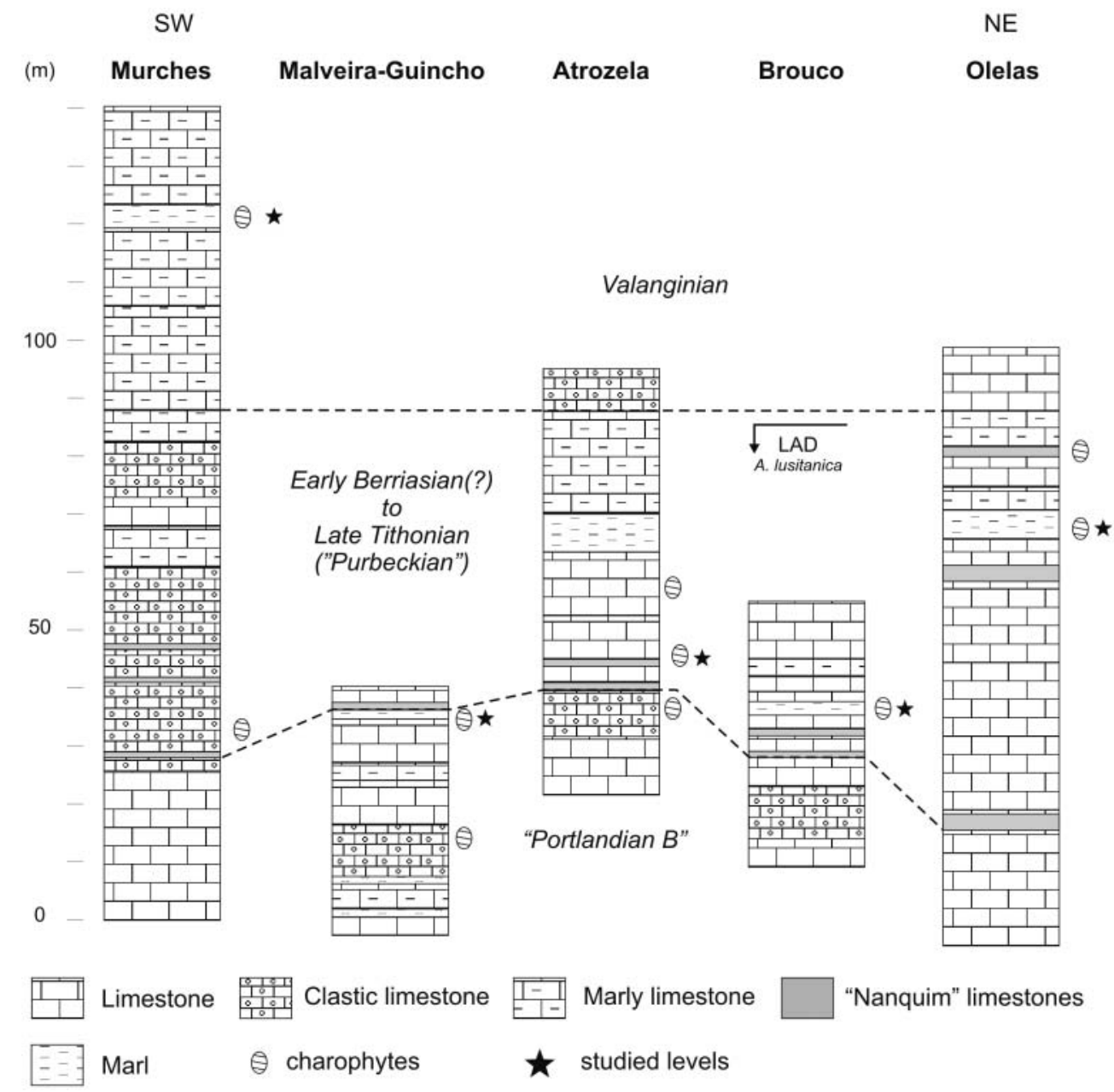

Fig. 3. Simplified lithostratigraphical columns and correlation of the interval at the five studied sections (based on Ramalho, 1971, simplified).

- The top of the Upper Jurassic is characterized by alternation of restricted, lagoonal marine deposits with abundant Anchispirocyclina lusitanica (Egger), other foraminifers and dasyclads (see description of sections) with terrestrially influenced deposits rich in charophytes and ostracods.

- For correlation purposes, Ramalho (1971) considered the base of the 'Purbeckian' interval marked by the first bed of a distinct local lithotype - a yellow, ferruginous clastic limestone traditionally known as 'Calcário amarelo-nanquim' (Choffat, 1901), which only occurs at the lowermost part of this interval. These yellow limestones are rich in charophytes (stems and gyrogonites) and ostracods.

- The upper limit of the same interval is marked by the disappearance of Anchispirocyclina lusitanica whose individuals, in addition, show consistently very high numbers and aberrant growth-types towards the top of the interval. Other differences within the foraminiferal fauna as compared to that in the Valanginian above were also clearly identified by Ramalho (1971). A. lusitanica has a high biostratigraphical value because it is documented to disappear at the JurassicCretaceous transition (basal Berriasian at the most) in the entire western peri-Tethyan realm (Bassoulet, 1997).

\section{DESCRIPTION OF THE STUDIED SECTIONS}

A brief description of the sections from which the studied charophyte material was obtained is presented below, covering only the part of the successions relevant for this study (uppermost Jurassic-lowermost Cretaceous). Figure 3 presents the schematic lithostratigraphical columns of the considered sections, with a correlation of the studied interval at the five locations.

\section{Murches}

As fully described by Ramalho (1971), the latest Tithonian (uppermost Portlandian B) of this section is approximately $28 \mathrm{~m}$ thick, being composed of micritic limestones, clastic towards the top (Fig. 3), with a few molluscs, foraminifers and dasyclads (Ramalho, 1971). The foraminifers include Nautiloculina oolithica (Mohler), Pseudocyclammina lituus (Yokoyama), Anchispirocyclina lusitanica (Egger), Trocholina gr. alpinaelongata, miliolids; the dasyclads, Salpingoporella annulata (Carozzi).

The 'Purbeckian' of this section shows, from the base towards the top, a $60 \mathrm{~m}$ thick succession comprising yellow limestones (the 'Calcários amarelo-nanquim' or 'Calcários Inferiores' sensu 
Choffat, in Ramalho, 1971), rich in charophytes and ostracods, overlain by alternating marls and limestones grading upwards into most common limestones. In the marly levels, the foraminifera assemblage is restricted to Anchispirocyclina lusitanica (with very abundant individuals), but it is of much higher diversity in the limestones, comprising Nautiloculina oolithica, Feurtillia frequens (Maync), Pseudocyclammina lituus, Anchispirocyclina lusitanica, Rectocyclammina chouberti (Hottinger), Trocholina gr. alpina-elongata, miliolids and verneulinids (Ramalho, 1971). Also significant is the occurrence of dasyclads, such as Salpingoporella annulata and Cylindroporella cf. arabica (Elliot) (Ramalho, 1971), and of ostracods, such as Stenestroemia sp., Schuleridea sp., Paracypris sp. and Asciocythere sp. (M. C. Cabral identification).

Charophytes occur in Valanginian level 50 of Ramalho (1971), a yellow to greenish marly bed bearing Pseudocyclammina lituus, with the ostracods Cypridea gr. valdensis, Mantelliana purbeckensis, Darwinulla leguminella, Schuleridea sp., Cytheropteron sp. and Cytherella turgida. Charophyte association includes Globator maillardi nurrensis Pecorini, 1969 previously reported as G. maillardi var. (e.g. Schudack, 1993a), Nodosoclavator bradleyi (Harris, 1961) Grambast, 1966, and a new description of Clypeator cf. discordis Shaikin, 1976 and Porochara jaccardi (Heer, 1865) Mojon, 1989.

\section{Malveira-Guincho}

This section, described by Ramalho (1971) as Corte $\mathrm{n}^{\circ} 1$, ranges throughout the Late Tithonian (Portlandian B according to this author) into the 'Purbeckian'. The Late Tithonian interval (about $42 \mathrm{~m}$ thick) corresponds to massive limestones (often clastic), marly limestones and marls (Fig. 3), bearing diverse foraminifera, Anchispirocyclina lusitanica, Rectocyclammina chouberti, Pseudocyclammina lituus, Everticyclammina virguliana (Koechlin), Nautiloculina oolithica, Trocholina gr. alpinaelongata and miliolids; ostracods (Paracypris sp., Cytheropteron sp.); dasyclads and charophytes; shell remains and coprolites (Ramalho, 1971). The present work, using samples from three different levels (Fig. 3), confirms the occurrence of Nodosoclavator bradleyi (already identified by Ramalho, 1971) and highlights the new occurrence of Porochara jaccardi (Heer, 1865) Mojon, 1989.

The 'Purbeckian' ( $4 \mathrm{~m}$ ) is recognized by a basal bed of the typical yellow ferruginous limestone ('Calcários amarelonanquim'), overlain by grey massive limestones, interbedded with a thin yellow marl layer; only miliolids occur in the grey limestones (Ramalho, 1971; Rey, 1972).

\section{Atrozela}

This section (Fig. 3), described by Ramalho (1971) as Corte $n^{\circ} 2$, displays Late Tithonian (Portlandian B pro parte) limestones (often clastic and nodular) and marls (over $18 \mathrm{~m}$ ), bearing: foraminifera (Feurtillia frequens, Pseudocyclammina lituus, Anchispirocyclina lusitanica and other lituolids, Trocholina gr. alpina-elongata, miliolids); ostracods (Fabanella polita polita Martin); dasyclads; charophyte stems and oogonia of Nodosoclavator bradleyi and Porochara sp. (Ramalho, 1971; Rey, 1972).

The 'Purbeckian' (48 m) grades from yellow ferruginous limestones (the 'Calcários amarelo-nanquim') at the base, to grey limestones and marly limestones, massive, nodular and clastic limestones and marls with gastropod fragments, Anchispirocyclina lusitanica, Everticyclammina virguliana, Rectocyclammina chouberti, other lituolids, miliolids, dasyclads (Salpingoporella annulata, Clypeina inopinata (Favre), Permocalculus sp.

The previously recorded charophyte association includes Porochara sp., Nodosoclavator bradleyi, Clavator cf. reidi Groves, 1924, Globator maillardi (Saporta, 1891) Grambast, 1966 and Dictyoclavator cf. fieri (Donze, 1955) Grambast, 1966) (Ramalho, 1971; Rey, 1972). The new evaluation of four samples from levels 1, 2 and 3 of Ramalho (1971) and two samples from J. Rey (Grambast collection) yielded Nodosoclavator bradleyi and Clavator reidi, and further indicated the new occurrences of Porochara jaccardi, Mesochara harrisi and Globator rectispirale (a revision of $G$. maillardi). This association points to a Late Tithonian to Early Berriasian (?) age.

\section{Brouco}

The Brouco section is a sequence (over $60 \mathrm{~m}$ thick) of Late Tithonian (Portlandian B pro parte) massive and nodular limestones, interbedded with thin marl layers (Fig. 3), with diverse foraminifera (e.g. Nautiloculina oolithica, Freixialina planispiralis (Ramalho), Anchispirocyclina lusitanica, Pseudocyclammina lituus, miliolids) and dasyclads (Ramalho, 1971). Above, the 'Purbeckian' (equivalent to the Berriasian of Rey, 1972; Fig. 2) yellow limestones interbedded with grey limestones, overlain by $>20 \mathrm{~m}$ of thinner-bedded limestones and marly limestones, bear Feurtillia frequens, Anchispirocyclina lusitanica (which, in a few marly levels, is the single species, with many individuals), Pseudocyclammina lituus, Trocholina gr. alpina-elongata, Permocalculus sp., Clypeina cf. inopinata and ostracods, such as Cypridea tumescens praecursor (Oertli), Theriosynoecum forbesii (Jones) and Fabanella polita polita (Ramalho, 1971; Rey, 1972).

The charophyte assemblage, as revealed from the study of five samples from unit 4 of Rey (1972), comprises Globator rectispirale, Nodosoclavator bradleyi, Clypeator cf. discordis (species already reported by Ramalho, 1971 and Rey, 1972), Porochara jaccardi, Aclistochara sp., Mesochara harrisi and nodosoclavatoroide utricles (sensu Schudack, 1993a) with new occurrences now identified in this section. This association suggests a Late Tithonian to Early Berriasian (?) age.

\section{Olelas}

The Olelas section ranges from the Tithonian (Portlandian A and Portlandian B of Ramalho, 1971) to the Valanginian, with a succession of nodular limestones (sometimes clastic) and limestones (Fig. 3). The uppermost part of the Late Tithonian was described by Ramalho (1971) as more than $70 \mathrm{~m}$ of grey, massive or clastic limestones, commonly with irregular yellowish spots and, locally, a bivalve coquina. The fossil content includes molluscs, echinoids, Nautiloculina oolithica, Anchispirocyclina lusitanica, Everticyclammina virguliana, Rectocyclammina chouberti, Trocholina gr. alpina-elongata, miliolids, Salpingoporella annulata and Cylindroporella cf. arabica, among other taxa.

The 'Purbeckian' (60-80 m) presents massive, yellow and grey limestones with marly intercalations, bearing mollusc remains, crustaceans, coprolites, sponge spicules, Nautiloculina oolithica, Anchispirocyclina lusitanica, Everticyclammina virguliana, miliolids, Permocalculus sp., dasyclads and ostracods, 

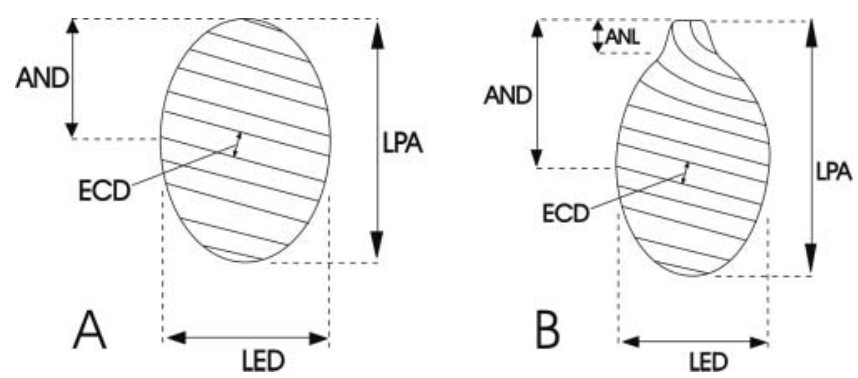

Fig. 4. Simplified scheme of some of the measured parameters in a gyrogonite (see text for description of parameters): (A) forms without apical neck; (B) forms with apical neck.

such as Fabanella polita polita (Ramalho, 1971). Charophytes occur in a marly bed, which bears Globator rectispirale, Nodosoclavator bradleyi, Porochara jaccardi, Mesochara harrisi, nodosoclavatoroide utricles and Porochara sp., of Late Tithonian-Early Berriasian(?) age. Above, in deposits assigned by Rey (1972) to the 'Margo-calcários com Mantelliana purbeckensis' unit, this author mentions the occurrence of Porochara cf. maxima (Donze, 1955) Donze, 1958 emend. Mojon and Clavator reidi.

\section{POPULATION ANALYSIS}

Analysis of charophyte populations was made measuring distinct morphological parameters (Fig. 4), from which morphometric ratios were derived, following several reference works (Peck, 1937; Mädler, 1952; Horn \& Rantzien, 1956; Bonnet \& Soulié-Märsche, 1971; Soulié-Märsche et al., 1991; SouliéMärsche \& Joseph, 1991; Schudack, 1993a): LPA, length of polar axis $(\mu \mathrm{m})$; LED, length of equatorial distance $(\mu \mathrm{m}) ; \mathrm{NC}$, number of convolutions; ECD, equatorial cell diameter $(\mu \mathrm{m})$; AND, anisopolarity distance $(\mu \mathrm{m})$; APD, apical pore diameter $(\mu \mathrm{m})$; and BPD, basal pore diameter $(\mu \mathrm{m})$.

In an attempt to better describe the morphological variation in those forms that show a particular character, such as Clavatoraceae forms with apical necking (Fig. 4), additional parameters were applied: ANL, apical neck length $(\mu \mathrm{m})$; and AACD, apical annular cell diameter $(\mu \mathrm{m})$ - applied to the cells of the 'Ringstruktur' (Schudack, 1993a).

ANL allows the characterization of the dimension of the apical neck and, therefore, reduces the effect of this character in the sphericity and asymmetry ratios. Using these parameters, the form of the gyrogonite can then be described for the sphericity index (ISI) and anisopolarity index (ANI). The ISI, isopolarity index (sphericity), for gyrogonites without apical necking is

$$
I S I=\frac{L P A}{L E D} \times 100
$$

\begin{tabular}{lrrrrrrrr}
\hline & LPA & LED & NC & AND & ISI & ANI & ECD & BPD \\
\hline Average & 294 & 246 & 7 & 137 & 119 & 47 & 40 & 21 \\
Median & 294 & 245 & 7 & 137 & 119 & 47 & 39 & 20 \\
Minimum & 216 & 206 & 6 & 98 & 100 & 36 & 20 & 20 \\
Maximum & 353 & 294 & 10 & 176 & 141 & 57 & 59 & 29 \\
$n$ & 103 & 103 & 103 & 103 & 103 & 103 & 59 & 43 \\
\hline
\end{tabular}

Table 1. Statistics for morphometric parameters (Fig. 4) of the studied populations of Mesochara harrisi.

\begin{tabular}{lrrrrrrrr}
\hline & LPA & LED & NB & AND & ISI & ANI & APD & BPD \\
\hline Average & 1068 & 851 & 14 & 583 & 126 & 54 & 137 & 78 \\
Median & 1049 & 843 & 15 & 588 & 127 & 53 & 137 & 78 \\
Minimum & 902 & 706 & 11 & 490 & 101 & 49 & 118 & 78 \\
Maximum & 1275 & 1000 & 15 & 765 & 151 & 60 & 157 & 78 \\
$n$ & 21 & 21 & 7 & 18 & 20 & 17 & 4 & 1 \\
\hline
\end{tabular}

Table 2. Statistics for morphometric parameters (Fig. 4) of the studied populations of Globator rectispirale.

or with apical necking is

$$
I S I=\frac{L P A-A N L}{L E D} \times 100
$$

The ANI, anisopolarity index (asymmetry), for gyrogonites without apical necking is

$$
A N I=\frac{A N D}{L P A} \times 100
$$

or with apical necking is

$$
A N I=\frac{A N D-A N L}{L P A-A N L} \times 100
$$

Statistical analysis was applied to the parameters measured from every specimen in order to calculate average, median, minimum and maximum. Results from each species are compiled in Tables 1-7. The parameter $n$ refers to the number of specimens measured within a population.

The use of the morphometric parameters in population analysis is of significant importance for species definition, mainly in the case of Porocharaceae and Characeae, as confirmed in previous studies on a large population of Oxfordian charophytes from the Lusitanian Basin (Pereira et al., 2003). In addition, this kind of approach is also relevant for some forms of Clavatoraceae devoid of utricle calcification (e.g. Pereira \& Cabral, 2005), for which population analysis is often required for a thorough evaluation and systematics.

\begin{tabular}{lcccccrrrrr}
\hline & LPA & LED & NC & AND & ISI & ANI & APD & BPD & ANL & AACD \\
\hline Average & 575 & 391 & 9 & 307 & 134 & 48 & 69 & 39 & 53 & 26 \\
Median & 569 & 392 & 10 & 304 & 132 & 48 & 69 & 39 & 59 & 29 \\
Minimum & 402 & 304 & 8 & 225 & 110 & 29 & 20 & 10 & 0 \\
Maximum & 765 & 510 & 11 & 431 & 185 & 76 & 118 & 78 & 176 & 39 \\
$n$ & 204 & 201 & 12 & 191 & 201 & 189 & 175 & 99 & 200 \\
\hline
\end{tabular}

Table 3. Statistics for morphometric parameters (Fig. 4) of the studied populations of Nodosoclavator bradleyi. 


\begin{tabular}{lrrrrrrrr}
\hline & LPA & LED & AND & ISI & ANI & APD & BPD & ANL \\
\hline Average & 612 & 460 & 312 & 122 & 45 & 77 & 53 & 69 \\
Median & 608 & 451 & 314 & 121 & 47 & 78 & 44 & 78 \\
Minimum & 431 & 353 & 167 & 88 & 19 & 39 & 20 & 0 \\
Maximum & 784 & 598 & 431 & 156 & 65 & 118 & 118 & 157 \\
$n$ & 114 & 105 & 85 & 105 & 85 & 43 & 18 & 97 \\
\hline
\end{tabular}

Table 4. Statistics for morphometric parameters (Fig. 4) of the studied populations of Clavator reidi.

The methodology applied in the present work is an attempt to fully depict problematic taxa and to provide their complete description, as with Porochara jaccardi and Mesochara harrisi. Due to the complex systematics of these forms, several different methods were applied: (1) traditional population analysis using statistical parameters as average, median, mode, minimum and maximum; (2) graphical plots such as LPA vs. LED; and (3) Box and Whisker plots. The latter set of plots displays the range of data from a population where the whiskers reflect the total dispersion of a particular parameter; the box reflects the amount of data that fits into the interval which contains $50 \%$ of the measured values. This is helpful to assess the scattering of measurements that fall out of the box, reflecting population variation regarding a similar character.

Figure 5 is a projection of the population of Porochara jaccardi using all the values from the different studied sections. Dashed areas indicate the population variation from reference values of Mädler (1952), Mojon (1989) and Schudack (1993a).

\section{SYSTEMATIC PALAEONTOLOGY (R. PEREIRA AND M. FEIST)}

Phylum Charophyta Migula, 1897

Class Charophyceae Smith, 1938

Order Charales Lindley, 1836

Family Characeae Agardh, 1824

Genus Mesochara Grambast, 1962

Mesochara harrisi (Mädler, 1952) Shaikin, 1967

(P1. 1, figs 7-10)

1952 Tolypella harrisi Mädler: 31, pl. B, figs 31-35.

1967 Mesochara harrisi (Mädler); Shaikin: 47.

1986 Tolypella harrisi (Mädler); Martín-Closas \& GrambastFessard: 49, pl. X, figs 9-12.

1989 Mesochara amoena (Mädler) Shaikin; Schudack: 424, pl. 5, figs 5-7.

1996a Mesochara harrisi (Mädler) Shaikin; Schudack: 160, pl. 2, figs 5-7.

1999 Mesochara harrisi (Mädler) Shaikin; Schudack: 203, pl. 1, figs 5-8.

Locality. Olelas, Atrozela and Brouco.

Age. Late Tithonian to Early Berriasian(?).

Description. Gyrogonites ranging from 216 to $353 \mu \mathrm{m}$ in length (Table 1), 206 to $294 \mu \mathrm{m}$ in width. Spherical to ovoid shape, with

\begin{tabular}{|c|c|c|c|c|c|c|c|c|c|c|}
\hline & LPA & LED & $\mathrm{NC}$ & AND & ISI & ANI & APD & ECD & BPD & ANL \\
\hline Average & 573 & 338 & 8 & 296 & 146 & 44 & 65 & 55 & 34 & 82 \\
\hline Median & 569 & 333 & 8 & 294 & 143 & 44 & 59 & 49 & 39 & 78 \\
\hline Minimum & 490 & 294 & 7 & 206 & 118 & 25 & 49 & 39 & 20 & 0 \\
\hline Maximum & 725 & 412 & 10 & 412 & 184 & 53 & 78 & 78 & 59 & 157 \\
\hline$n$ & 32 & 32 & 32 & 32 & 32 & 32 & 25 & 25 & 17 & 32 \\
\hline
\end{tabular}

Table 5. Statistics for morphometric parameters (Fig. 4) of the studied populations of nodosoclavatoroide utricle.

\begin{tabular}{lcccccrrrr}
\hline & LPA & LED & NC & AND & ISI & ANI & APD & ECD & BPD \\
\hline Average & 524 & 403 & 10 & 270 & 130 & 52 & 52 & 61 & 34 \\
Median & 539 & 412 & 10 & 275 & 129 & 51 & 49 & 59 & 39 \\
Minimum & 373 & 294 & 8 & 196 & 108 & 46 & 20 & 39 & 20 \\
Maximum & 647 & 520 & 12 & 363 & 157 & 71 & 108 & 88 & 59 \\
$n$ & 129 & 129 & 128 & 126 & 129 & 126 & 85 & 39 \\
\hline
\end{tabular}

Table 6. Statistics for morphometric parameters (Fig. 4) of the studied populations of Porochara jaccardi.

\begin{tabular}{|c|c|c|c|c|c|c|c|c|c|}
\hline & LPA & LED & $\mathrm{NC}$ & AND & ISI & ANI & APD & ECD & BPD \\
\hline Average & 771 & 614 & 10 & 397 & 126 & 51 & 102 & 90 & 53 \\
\hline Median & 765 & 608 & 10 & 402 & 126 & 51 & 98 & 88 & 59 \\
\hline Minimum & 608 & 490 & 8 & 314 & 114 & 49 & 78 & 59 & 39 \\
\hline Maximum & 941 & 824 & 12 & 480 & 147 & 59 & 137 & 118 & 78 \\
\hline$n$ & 71 & 71 & 71 & 71 & 71 & 71 & 52 & 51 & 30 \\
\hline
\end{tabular}

Table 7. Statistics for morphometric parameters (Fig. 4) of the populations of Porochara maxima. 


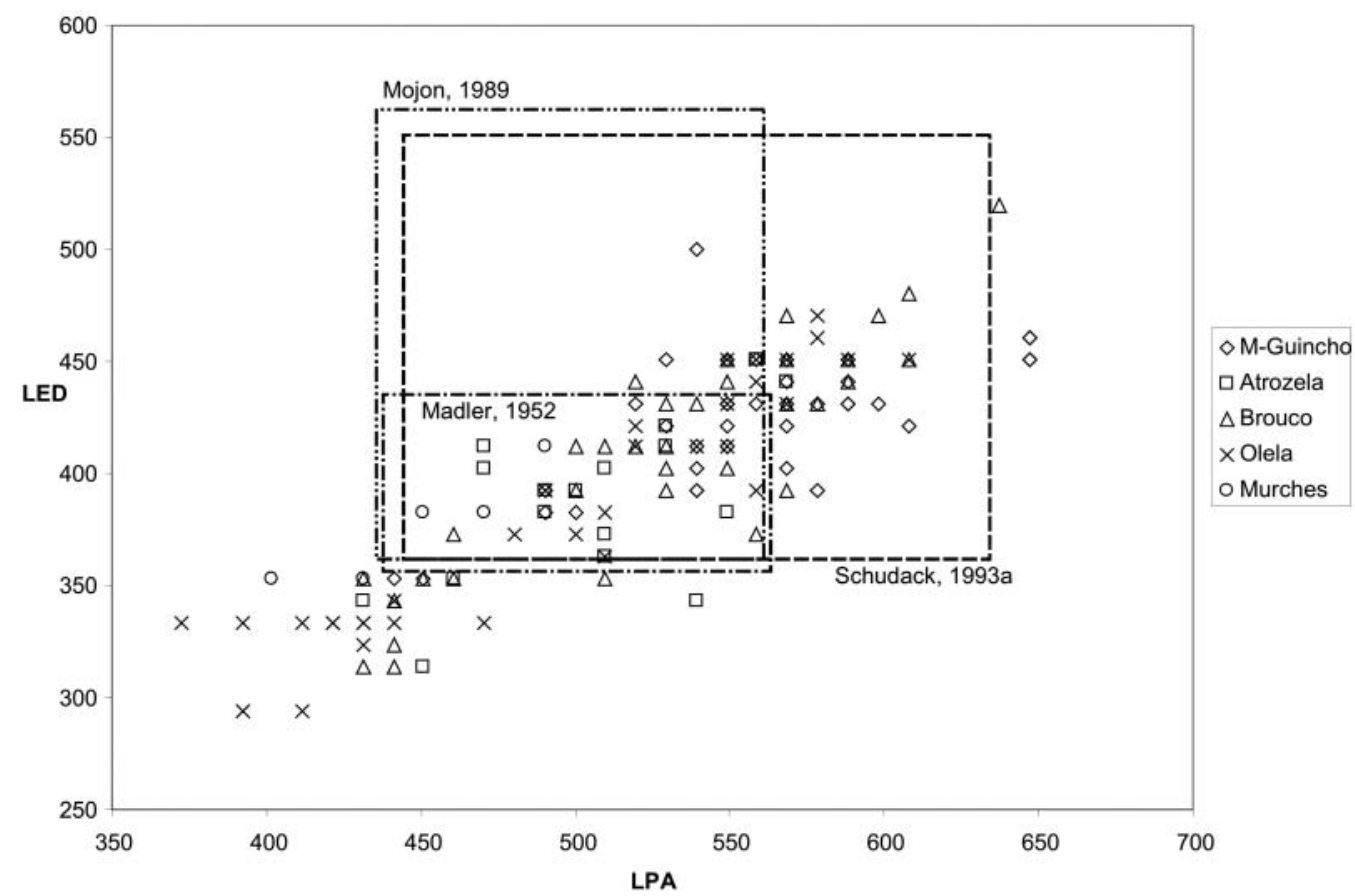

Fig. 5. Graphical projection of the populations of Porochara jaccardi for the studied sections. Dashed areas represent the reference values (Mädler, 1952; Mojon, 1989; Schudack, 1993a) for this form.

larger apical half (ANI averages 47), presenting ISI ratios of 100 to 141 , but common values average 119 . With 6-10 concave to convex spiral cells, averaging $40 \mu \mathrm{m}$ in width. Basal pore diameter small, (on average $21 \mu \mathrm{m}$ ), at the end of a conical half. Basal plate could not be isolated or identified. Apical pore closed, usually of conical to rounded shape.

Occurrence. Similar forms have been described from the Kimmeridgian to Berriasian of Germany (Schudack, 1993a; 1996a), the Kimmeridgian of Spain (Schudack, 1993a) and the Berriasian of Spain and France (Martín-Closas \& GrambastFessard, 1986; Schudack, 1989), also from the Kimmeridgian/ Tithonian of the former USSR (Shaikin, 1967), the Lower Cretaceous of China (Schudack, 1993a) and the Upper Jurassic of Tanzania (Schudack, 1999).

Remarks. The systematics of Mesochara is, at present, still under discussion (Schudack, 1993a; Martín-Closas, 2000) due to the great similarities between the different species originally described mainly by Mädler (1952). When comparing the studied samples of Mesochara, several possible species could be accepted. In the case of $M$. harrisi, graphical analysis (Fig. 6) shows that populations are strongly variable, although the majority of the data (LPA and LED) are plotted within the interval defined by the original description of Mädler (1952). Figures 7 and 8 are box and whisker plots for LPA, LED and ISI for the studied populations.

In addition, when considering the overall shape and morphological parameters, i.e. its population dimensions, sphericity, symmetry and number of spiral cells, the closest form accepted is Mesochara harrisi. Mesochara voluta (Peck, 1937) Grambast, 1965 is larger in size, whereas in M. minuta (Mädler, 1952)
Shaikin, 1955 and M. canellata (Mädler, 1952) Shaikin, 1967, the studied population is larger (Schudack, 1996a).

Family Clavatoraceae Pia, 1927

Subfamily Atopocharoideae (Peck, 1957) Grambast, 1969

Genus Globator Grambast, 1966

Globator rectispirale (Feist et al., 1995)

(P1. 1, figs 20-21)

1971 Globator maillardi (Saporta); Ramalho: 181, pl. 33, fig 7. 1972 Globator maillardi (Saporta); Rey: 38, 43, 50.

1995 Globator rectispirale Feist; Feist et al.: 412, pl. 1, figs 1, 5.

Locality. Brouco, Atrozela and Olelas.

Age. Late Tithonian.

Description. Utricle of Globator, with three groups of cells vertically aligned. Each group comprises one basal cell and three upper cells. General shape is globular to ovoid with asymmetrical halves in longitudinal view, of which the basal half is larger. In apical view, the shape is roughly triangular. Large-sized utricle (average length $1068 \mu \mathrm{m}$ and $851 \mu \mathrm{m}$ in width) with sphericity index and asymmetry averaging 126 and 54, respectively (Table 2 ). With $11-15$ bract cells (NB) vertically aligned from the basal half.

Occurrence. In Portugal this form has been described from Brouco (Ramalho, 1971; Feist et al., 1995); in England, from the Late Tithonian of the Lulworth Formation (key correlation Zone 1) and from the Tithonian of Algeria (Feist et al., 1995). 

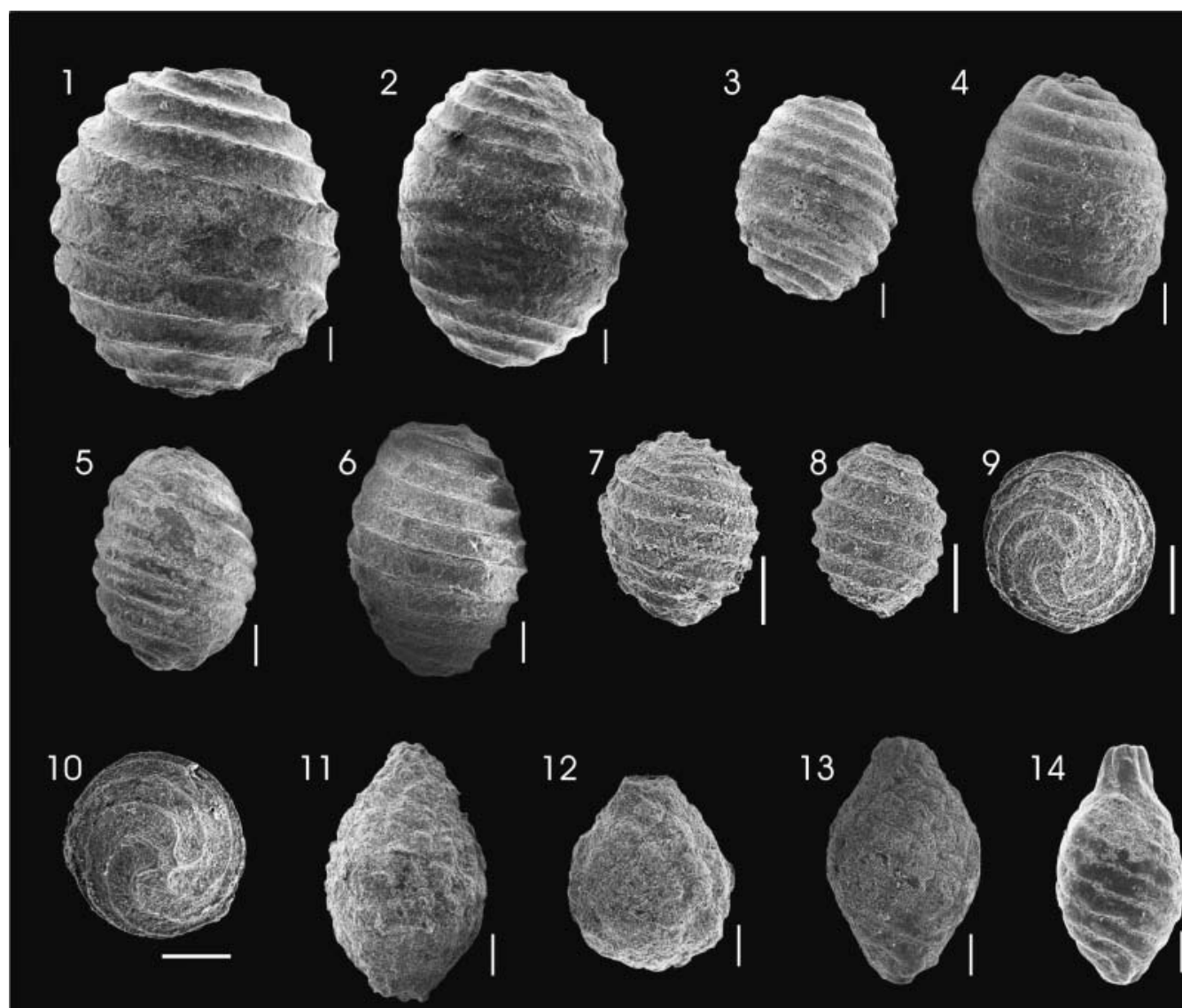

12
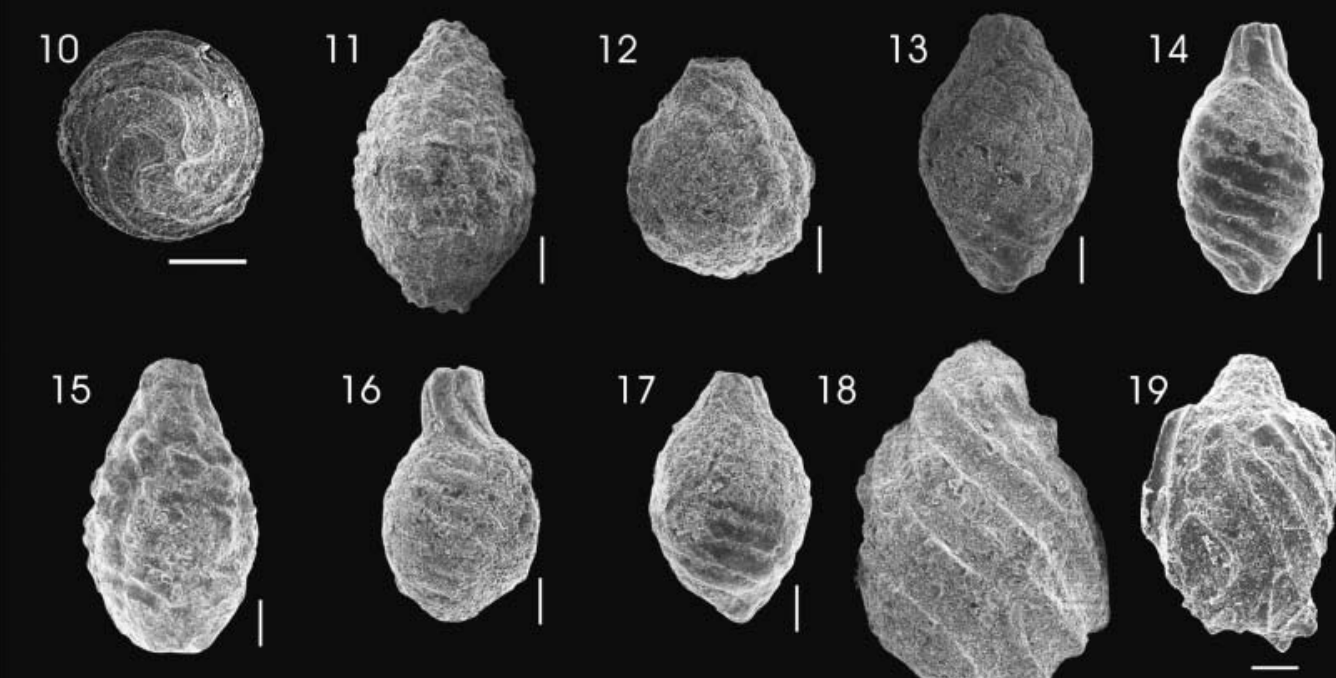

18
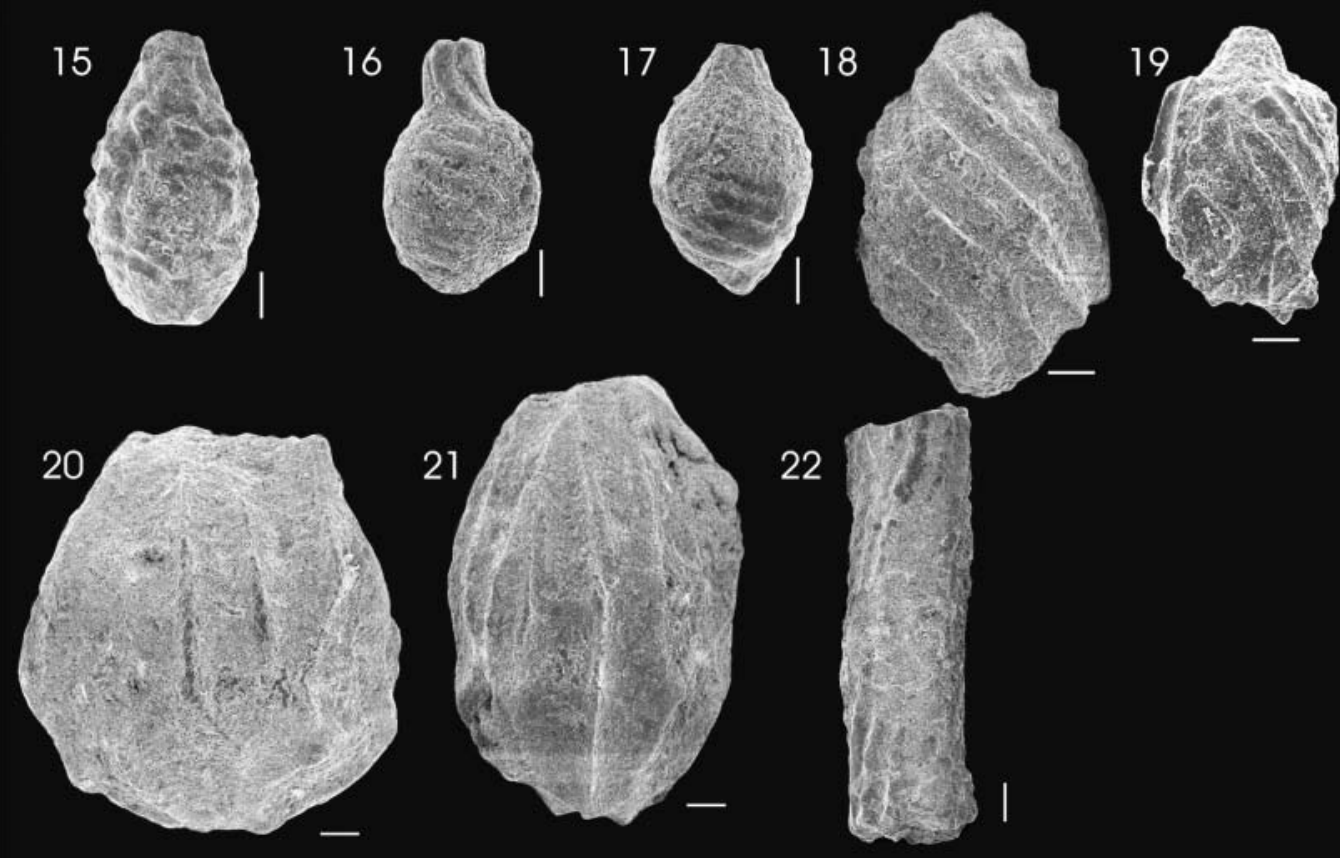

Explanation of Plate 1.

figs 1-3. Porochara maxima (Donze) Donze; Mojon; lateral view; Olelas. figs 4-6. Porochara jaccardi (Heer) Mojon; lateral view: 4, 5, Brouco; 6, Olelas. figs 7-10. Mesochara harrisi (Mädler) Shaikin: 7, 8, lateral view, Olelas; 9, apical view, Olelas; 10, basal view, Olelas. figs 11-13. Nodosoclavator bradleyi (Harris) Grambast; lateral view: 11, 12, Atrozela; 13, Olelas. figs 14-17. nodosoclavatoroide utricle Schudack; lateral view; Olelas. figs 18, 19. Clavator reidi Groves; lateral view: 18, Atrozela; 19, Olelas. figs 20, 21. Globator rectispirale Feist; lateral view; Brouco. fig. 22. Charaxis sp. Harris; Olelas. White rule is $100 \mu \mathrm{m}$. 


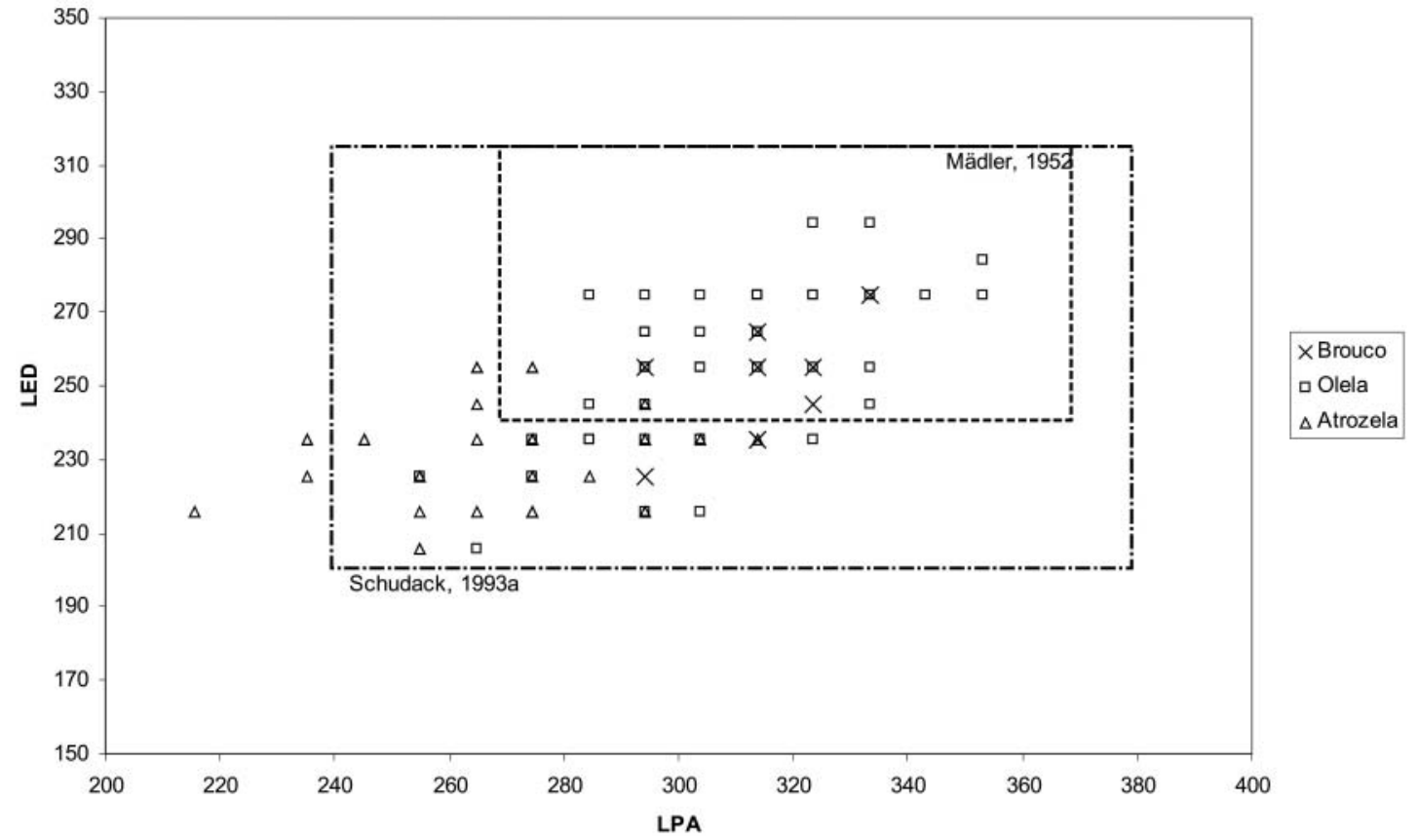

Fig. 6. Graphical projection of the populations of Mesochara harrisi for the studied sections. Dashed area represents the reference values (Mädler, 1952; Schudack, 1993a) for this form.
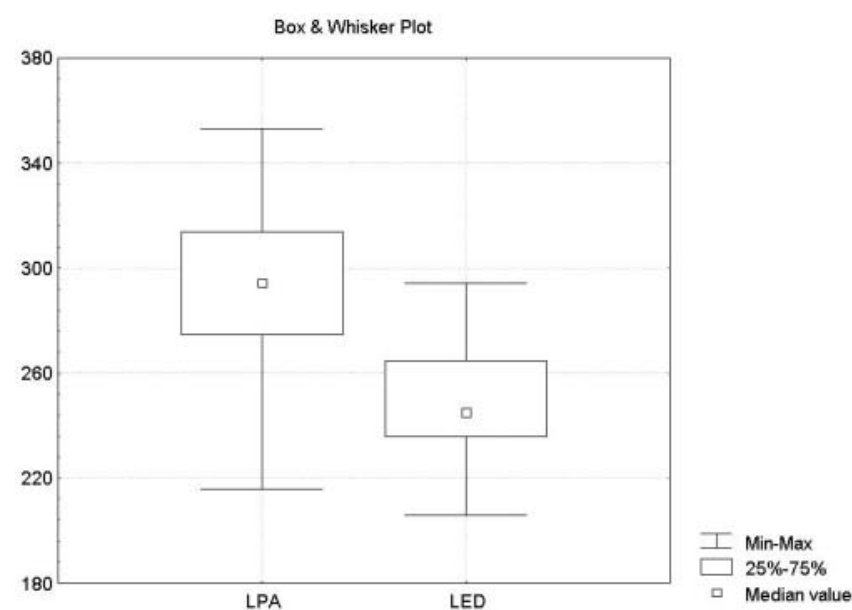

Fig. 7. Box and whisker plot of LPA and LED for the studied populations of Mesochara harrisi.

Remarks: The evolutionary trend of the Globator utricle is characterized by the progressive spiralization of the long upper cells and the reduction of the short basal ones. The studied specimens show vertical long cells, which give these samples a primitive feature.

Subfamily Clavatoroidae Pia, 1927, emend. Grambast, 1969

Genus Nodosoclavator (Maslov, 1961) Grambast, 1966

Nodosoclavator bradleyi (Harris, 1961) Grambast, 1969 (Pl. 1, figs 11-13)

1939 Clavator bradleyi Harris: 53-54, pl. XVI, figs 1, 3-5, 7. 1957 Clavator nodosus Peck: 8, figs 3-18.

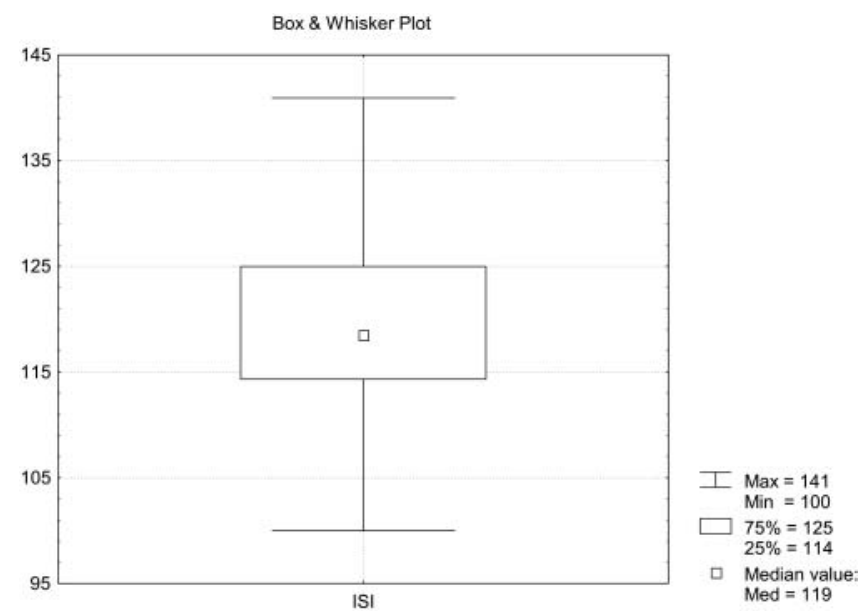

Fig. 8. Box and whisker plot of ISI ratio for the studied populations of Mesochara harrisi.

1969 Nodosoclavator bradleyi (Harris); Grambast: 878.

1971 Nodosoclavator bradleyi (Harris) Grambast; Ramalho: 182, pl. 33, fig. 5 .

1972 Nodosoclavator bradleyi (Harris) Grambast; Rey: 38, 43, 50.

1987 Nodosoclavator bradleyi (Harris) Grambast; Mojon \& Strasser: 45, pl. 9, P.

2000 Nodosoclavator bradleyi (Harris) Grambast; MartínClosas: 121, pl. 12, figs 1-2.

Locality. Malveira-Guincho, Olelas, Atrozela and Brouco.

Age. Late Tithonian to Early Berriasian(?). 
Description. Utricle with ellipsoidal bottle shape, with larger basal half. Apical half with a well-defined apical neck, but forms without this feature are also present. Utricle often showing bracteal impressions at the basal half and revealing the nodular layer, which covers totally or partially the gyrogonite. Five circular cells ('Ringstruktur') at the apical pore, ranging from 20 to $39 \mu \mathrm{m}$ (Table 3); apical pore diameter averaging $69 \mu \mathrm{m}$. Medium-sized utricle, with $402-765 \mu \mathrm{m}$ in length, and width from $304-510 \mu \mathrm{m}$. When visible, 8-12 (usually 9) concave spiral cells can be seen laterally. Sphericity index of the 'body' of the utricle averages 134 , but for the whole specimen including the apical projection, ISI averages 148. Apical neck length is variable and, when present, can reach up to $176 \mu \mathrm{m}$, but average values are of $53 \mu \mathrm{m}$.

Occurrence. In Portugal, this form is known from the 'Purbeckian' of the Algarve and Sintra-Cascais (Ramalho, 1971; Rey, 1972; Ramalho \& Rey, 1975); it is also reported from the Goldberg Formation of the Swiss Jura (Mojon \& Strasser, 1987), the Berriasian of Spain (Martín-Closas \& Salas, 1998; Martín-Closas, 2000) and northern Germany (Schudack, 1993a), the Lower Cretaceous of England (Harris, 1939), Odessa and Moldavia (Shaikin, 1976), from the Kimmeridgian to Tithonian of the USA (Peck, 1957) and China (Martín-Closas, 2000).

\section{Genus Clavator Reid \& Groves, 1916 \\ Clavator reidi Groves, 1924 \\ (Pl. 1, figs 18-19)}

1924 Clavator reidi Groves: 116.

1971 Clavator cf. reidi Groves; Ramalho: 182

1972 Clavator cf. reidi Groves; Rey: 43.

1993a Clavator reidi reidi (Groves) Martín-Closas; Schudack: 75, pl. 9, figs $1-7$.

1993b Clavator reidi reidi (Groves) Martín-Closas; Schudack: 53, pl. 2, fig. 2.

1995 Clavator reidi Groves; Feist et al.: 415, pl. 1, figs 9-13.

1996a Clavator reidi reidi (Groves) Martín-Closas; Schudack:

162, pl. 2, figs 11-12.

1996b Clavator reidi reidi (Groves) Martín-Closas; Schudack: 38, fig. 18.

2000 Clavator reidi reidi (Groves) Martín-Closas; MartínClosas: 128, pl. 13, figs 1-3.

Locality. Brouco, Olelas and Atrozela.

Age. Late Tithonian to Early Berriasian(?).

Occurrence. In Portugal this form was found in the Lower Cretaceous (Rey et al., 1968 in Feist et al., 1995; Ramalho, 1971). It is known from the Berriasian of Spain (Feist et al., 1995), the Lower Berriasian of Switzerland (Mojon \& Strasser, 1987) and the Berriasian of Germany (Feist et al., 1995; Schudack, 1993a, b, 1996a, b).

Description. Bottle-shaped utricle, formed by five sinistrogirous spiralled cells, rounded basal half and short apical neck. Utri- cular cells ranging from the base to the top, but sometimes covering only the basal half. Medium-sized utricle averaging $612 \mu \mathrm{m}$ in length and $460 \mu \mathrm{m}$ in width, with an average sphericity of 122, usually with larger apical half (Table 4). Apical pore medium to large and basal pore averaging $53 \mu \mathrm{m}$. Necking of apical region when present can be as high as $157 \mu \mathrm{m}$. Calcified utricle sometimes incomplete, showing nodular layer.

Genus Clypeator (Grambast, 1962) Grambast, 1970

$$
\text { Clypeator cf. discordis Shaikin, } 1976
$$

1970 Clypeator sp. Grambast: 1965, b, pl. I, fig. 3.

1971 Flabellochara grovesi (Harris) Grambast; Ramalho: 83, pl. 33, fig. 6.

1972 Flabellochara grovesi (Harris) Grambast; Rey: 38, fig. 50. 1974 Clypeator sp. Grambast: 475, fig. 7.2.

1976 Clypeator discordis Shaikin: 82, figs 9-11.

1989 Clypeator discordis Shaikin; Schudack: 421, pl. 4, figs 9-13. 1993a Clavator grovesii var. discordis (Shaikin) nov. comb.;

Schudack: 77-78, pl. 9, figs 15-18.

1995 Clypeator discordis Shaikin; Feist et al.: 418, pl. 2, figs 5-6. 2000 Clavator grovesii var. discordis (Shaikin) Schudack; Martín-Closas: 136-139, pl. 14, fig. 2.

Locality. Brouco.

Age. Late Tithonian.

Description. Poorly preserved medium-sized diamond-shaped utricle (larger at basal half), with bilateral symmetry. Vegetative cells form two groups of utricular coatings around the lateral pores.

Occurrence. In Portugal this form was described from the Brouco section (Ramalho, 1971; Feist et al., 1995). In Spain, Martín-Closas (2000) refers to its occurrence at the Lower Berriasian of the Cameros basin and at the Basque-Cantabrian basin. Similar forms are also described from the Late Tithonian of the Lulworth beds in England, the Berriasian of Germany (Schudack, 1993a), the Valanginian of China (Feist et al., 1995) and from the Hauterivian to Barremian of the Ukraine (Shaikin, 1976).

nodosoclavatoroide utricle Schudack, 1993a Clavatoroideae indet.

(P1. 1, figs 14-17)

1993a nodosoclavatoroide Schudack: 90, pl. 12, figs 9-15. 1993b nodosoclavatoroide; Schudack: 53, pl. 2, fig. 9. 1996a nodosoclavatoroide; Schudack: 163, pl. 2, fig. 13.

Locality. Brouco and Olelas.

Age. Late Tithonian.

Description. Clavatoraceae gyrogonite usually devoid of utricle calcification, with bottle shape and long apical neck. Presents 7-10 (usually 8) convex to flat spirals visible laterally, aligned 
vertically at the apex (Table 5). The utricle cover, when present, shows portions of the nodular layer and/or of bracteal impressions at the base. Length 490-725 $\mu \mathrm{m}$ and width $294-412 \mu \mathrm{m}$. The gyrogonite, excluding the apical neck, is markedly ellipsoidal (average ISI of 146), whilst the gyrogonite can range from 145 to 212 (average of 171). Marked apical necking $(82 \mu \mathrm{m}$ average length), often with vertical cells. Apical pore ranging from 49 to $78 \mu \mathrm{m}$, and basal pore averages $34 \mu \mathrm{m}$.

Occurrence. Apart from Portugal, similar specimens are known from the Berriasian of Germany (Schudack, 1993a, 1996a).

Remarks. Utricles similar to Nodosoclavator, but with incomplete or absent utricle cover. When comparing the apical neck, nodosoclavatoroide utricle usually has larger dimensions than Nodosoclavator bradleyi; the same applies to the overall dimensions and sphericity ratio (more elliptical).

Family Porocharaceae Grambast, 1962

Genus Porochara Mädler, 1955 emend. Schudack, 1986

Porochara jaccardi (Heer, 1865) Mojon, 1989

(Pl. 1, figs 4-6)

1865 Chara jaccardi n. sp. Heer: 218, fig. 134.

1952 Aclistochara hildesiensis n. sp.; Mädler: 18-19, pl. A, figs

17-21.

1955 Porochara hildesiensis (Mädler); Mädler: 271.

1971 Porochara sp., Ramalho: 50, 51, 59, 66, 67, 80, 83.

1972 Porochara sp., Rey: 38, 43, 49, 50.

1985 Musacchiella sardinae Feist \& Grambast-Fessard; Colin et al.: 348-350, pl. 1, figs 6-13.

1987 Porochara cf. hildesiensis (Mädler) Mädler; Mojon \& Strasser: figs 9F-J.

1989 Porochara jaccardi (Heer); Mojon: 509-512, pl. VI, figs A1-7, B1-15, C1-12.

1993a Porochara jaccardi (Heer) Mojon; Schudack: 53, pl. 3, figs $7-8$.

Locality. Atrozela, Malveira-Guincho, Olelas, Murches and Brouco.

Age. Late Tithonian to Early Berriasian(?)

Description. Medium-sized gyrogonite, with oval shape and larger basal half. In lateral view, usually 9-10 spiral concave to convex cells can be observed (Table 6), but specimens with 8-12 spiral cells are also present. Equatorial cell diameter averages $62 \mu \mathrm{m}$, apical pore small averaging $52 \mu \mathrm{m}$ and the basal pore diameter averages $34 \mu \mathrm{m}$. Truncated to rounded apex and rounded base are the most common features.

Occurrence. Porochara jaccardi has been described from the Kimmeridgian to Lower Tithonian(?) of Germany (Schudack, 1993a), the Berriasian of France and Switzerland (Heer, 1865; Mojon \& Strasser, 1987; Mojon, 1989) and Sardinia, Italy (Colin et al., 1985) and the Berriasian to Barremian of Spain (Martín-Closas \& Grambast-Fessard, 1986).
Porochara maxima (Donze, 1955) Donze, 1958

(P1. 1, figs 1-3)

1955 Aclistochara maxima Donze: 289, pl. 13, figs 6-7.

1958 Porochara maxima Donze: 180.

1972 Porochara cf. maxima (Donze) Donze; Rey: 49.

1989 Porochara maxima (Donze) Donze; Mojon: 508, pl. 3, figs

A-P, pl. 4, A1-7, B1-6, C1-15, pl. 5, B1-33.

1993a Porochara maxima (Donze) Donze; Schudack: 55, pl. 3, figs 18-21.

1995 Porochara maxima (Donze) Donze; Feist et al.: 410, pl. 2, fig. 21.

Locality. Olelas.

Age. Late Tithonian.

Description. Gyrogonite of Porochara of large size with ellipsoidal form, with rounded larger apical half. Spiral cells concave, often well marked. Gyrogonite with large apical pore $(102 \mu \mathrm{m}$ average) and truncated apex. 8-12 (commonly 10) concave spiral cells visible in lateral view. Basal pore averaging $53 \mu \mathrm{m}$. Equatorial cell diameter ranges from 59 to $118 \mu \mathrm{m}$.

Occurrence. This form is present in the Lower Berriasian of the French-Swiss Jura mountains (Donze, 1955; Mojon, 1989); in the Lower Berriasian of the Lulworth Formation, England (Feist et al., 1995), northwest Germany, Sardinia and Spain (Schudack, 1993a; Feist et al., 1995).

\section{Charaxis Harris, 1939}

(Pl. 1, fig. 22)

Locality. Olelas.

Description. Charophyte thalli with nodes and internodes showing longitudinal cortical cells spiralled along the main axis. In section, 12 cortical cells can be observed.

\section{DISCUSSION AND CONCLUSIONS}

The 'Purbeckian' facies of the Sintra-Cascais and Lisbon area (Portugal) are characterized by the occurrence of charophytes typical of the Late Tithonian-Early Berriasian interval. These deposits were formed in a lagoonal to lacustrine environment (e.g. Ramalho \& Rey, 1975), which allowed several species of charophytes to flourish under suitable oligo-haline to mesohaline conditions (sensu Schudack, 1993a).

Comparing the studied Portuguese charophyte floral assemblage with those described from other regions, namely those identified by Feist et al. (1995) from the Late Tithonian of the Lulworth Formation in England and from the Tithonian of the Mahjouba Formation in Algeria, allows better constraint on the stratigraphic positioning of the studied successions. The Lulworth succession presents, for Zone 1 (Late Tithonian; Feist et al., 1995), the occurrence of Globator rectispirale and Clypeator discordis, forms similar to those of the Sintra-Cascais and Lisbon region. Similarly, Feist et al. (1995) describe the occurrence of the former in the Mahjouba Formation of Algeria. Thus, the studied interval in all sections but Murches should 


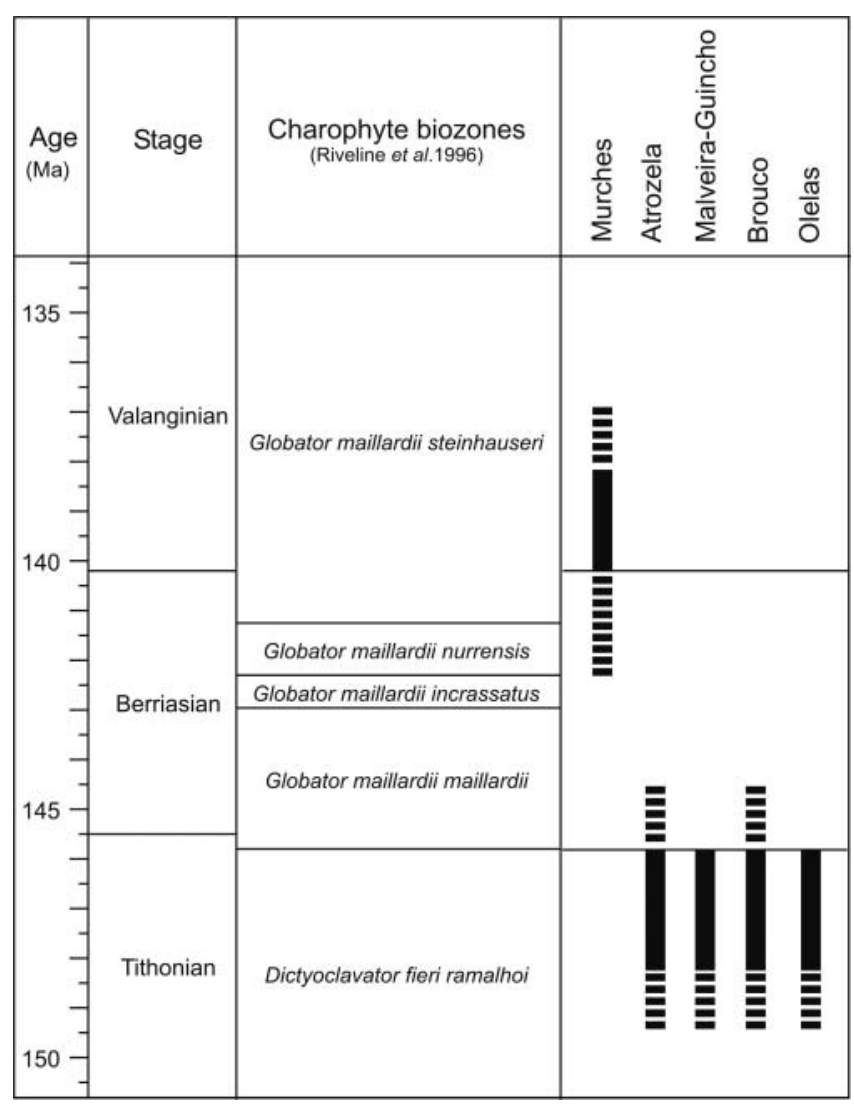

Fig. 9. Stratigraphical positioning of the studied charophytes and comparison with the biozones of Riveline et al. (1996). Dashed columns represent possible age extension.

now be considered to most likely represent a Late Tithonian age. This is in accordance with the fact stated by Feist et al. (1995) that Mantelliana purbeckensis, which used to be taken as indicating a Berriasian age, is now accepted to exist from the Late Jurassic.

This stratigraphical positioning in the Late Tithonian interval is reinforced by the fact that, whereas these Portuguese assemblages do not correlate with clear Cretaceous assemblages described elsewhere, they are broadly similar to those found in known European 'Purbeckian' successions, such as those from Spain (Martín-Closas \& Salas, 1998), Italy (Colin et al., 1985) and Switzerland (Mojon \& Strasser, 1987), even though exact age correlations cannot be made.

When comparing the assemblages presented herein to the biozones defined by Riveline et al. (1996), it is not possible to make a direct correlation to those formally defined biostratigraphical units of the Tithonian, as Globator maillardi maillardi was not reported. Therefore, a greater age is accepted, so that the studied sections are likely to belong to the Late Tithonian interval (Fig. 9), instead of the previously accepted wider 'Purbeckian' interval, i.e. Tithonian to Early Berriasian age.

The occurrence of these Late Tithonian forms in Portugal is important for palaeobiogeographical interpretations, considering the intermediate geographical position of Portugal relative to England and Algeria where similar assemblages were previously reported.
The Murches charophyte beds (Fig. 9) are considered to be Late Berriasian(?) to Valanginian, as evidenced by the occurrence of the association bearing Globator aff. nurrensis, a revision of G. maillardi var.

Statistical analysis applied to the studied charophytes has allowed better characterization of the population variation within each species. This methodology presents the best results when applied to families of charophytes with few distinguishing features, mainly to Characeae and Porocharaceae, forms without utricle covers. However, even for Clavatoraceae this approach is useful, since it allows enhancing the descriptive features with a more objective quantitative contribution to systematics.

\section{ACKNOWLEGEMENTS}

The authors are thankful to Michael Schudack (Germany) and John Gregory (UK) for helpful and constructive reviews of this paper. The authors also acknowledge the significant contribution of Carles Martín-Closas (Barcelona), whose comments on an earlier version of the work led to an important improvement in the original manuscript. Special thanks to M. Cristina Cabral (Portugal) for identification of the ostracods from the Murches section and to Miguel M. Ramalho (Portugal) for permission to study the charophyte collection.

\section{Manuscript received 9 February 2009 \\ Manuscript accepted 8 February 2010}

\section{REFERENCES}

Bassoullet, J.P. 1997. Les grands foraminifères. In: Cariou, E. \& Hantzpergue, P. (coords.), Biostratigraphie du Jurassique OuestEurropéen et Mediterranéen. Groupe Français d'étude du Jurassique. Bulletin du Centre Recherches Elf Exploration Production, Pau, 17: 293-304.

Bonnet, L. \& Soulié-Märsche, I. 1971. Méthodes quantitatives en paléontologie; Quelques applications à l'étude des charophytes. Bulletin de la Société d'Histoire Naturelle de Toulouse, 107(1-2): 28-57.

Choffat, P. 1901. Notice préliminaire sur la limite entre le Jurassique et le Crétacique en Portugal. Bulletin de la Société Belge de Géologie Paléontologie Hydrologie, XV: 111-140.

Colin, J.-P., Feist, M., Grambast-Fessard, N., Cherchi, A. \& Schroeder, R. 1985. Charophytes and ostracods from the Berriasian (Purbeckian facies) of Cala d'Inferno (Nurra region, NW Sardinia). Bulletino della Societá Paleontologica Italiana, 23(2): 345-354.

Donze, P. 1955. Nouvelles espèces de charophytes dans les niveaux de la limite Jurassico-Crétacée du Jura, des Alpes-Maritimes et de la Provence. Bulletin de la Societe Geologique de France 6eme Série, V(4-6): 287-290.

Donze, P. 1958. Les couches du passage du Jurassique au Crétacé dans le Jura français et sur les pourtours de la 'fosse vocontienne' (Massifs subalpins septentrionaux, Ardèche, Grands Causses, Provence, AlpesMaritimes). Thesis Université Lyon I, Travaux du Laboratoire de Géologie de la Faculte des Sciences de Lyon (nouvelle serie), 3: 1-221.

Feist, M., Lake, R.D. \& Wood, C.J. 1995. Charophyte biostratigraphy of the Purbeck and Wealden of southern England. Palaeontology, 38(2): 407-442.

Grambast, L. 1962. Classification de I'embranchement des Charophytes. Naturalia Monspeliensia, Série Botanique, 14: 63-86.

Grambast, L. 1965. Etat de Connaissances aquises sur les charophytes du Crétacé terminal. Comptes Rendus de l'Académie des Sciences, Paris, 258: 577-582.

Grambast, L. 1966. Un nouveau type structural chez les Clavatoracées; son intérêt phylogénétique et stratigraphique. Comptes Rendus de l'Académie des Sciences, Paris, Série D262: 1929-1932. 
Grambast, L. 1969. La symétrie de l'utricule chez les Clavatoracées et sa signification phylogénétique. Comptes Rendus de l'Académie des Sciences, Paris, Série D269: 878-881.

Grambast, L. 1970. Origine et évolution des Clypeator (Charophytes). Comptes Rendus de l'Académie des Sciences, Paris, Série D271: 1964-1967.

Grambast, L. 1974. Phylogeny of the Charophyta. Taxon, 23(4): 463481.

Groves, J. 1924. Clavator Reid et Groves. Journal of Botany, 62: $116-117$.

Harris, T.M. 1939. British Purbeck Charophyta. British Museum (Natural History), London, $83 \mathrm{pp}$.

Heer, O. 1865. Die Urwelt der Schweiz. Impr. Schulthess, Zürich, 800 pp.

Horn, A.F. \& Rantzien, H. 1956. Morphological terminology relating to female Charophyte gametangia and fructifications. Botaniska Notiser, 109(2): 212-259.

Mädler, K. 1952. Charophyten aus dem Nordwestdeutschen Kimmeridge. Geologisches Jahrbuch, 67: 1-45.

Mädler, K. 1955. Zur Taxionomie der tertiären Charophyten. Geologisches Jahrbuch, 70: 265-328.

Martín-Closas, C. 2000. Els caròfits del Juràssic superior I el Cretaci inferior de la Península Ibérica. Institut d'Estudes Catalans, Barcelona, Spain, 304 pp.

Martín-Closas, C. \& Grambast-Fessard, N. 1986. Les charophytes du Crétacé inférieur de la région du Maestrat (Chaîne Ibérique Catalanides, Espagne). Paléobiologie Continentale, XV: 1-66.

Martín-Closas, C. \& Salas, R. 1998. Lower Cretaceous biozonation in the Maestrat Basin (Iberian Ranges, Spain). A reply to P-O. Mojon (1996). Géologie Alpine, 74: 97-110.

Mojon, P.-O. 1989. Polymorphisme ecophénotypique et paléocologique des Porocharacées (charophytes) du Crétacé basal (Berriasien) du Jura franco-suisse. Révue de Paléobiologie, 8(2): 505-524.

Mojon, P-O. \& Strasser, A. 1987. Microfaciès, sédimentologie et micropaléontologie du Purbeckien de Bienne (Jura suisse occidental). Eclogae Geologicae Helvetiae, 1: 37-58.

Peck, R.E. 1937. Morrison Charophyta from Wyoming. Journal of Paleontology, 11(2): 83-90.

Peck, R.E. 1957. North American Mesozoic Charophyta. Geological Survey Professional paper, 294-A, 44 pp.

Pecorini, G. 1969. Le Clavatoraceae del 'Purbeckiano' di Cala d'Inferno nella Nurra di Alghero (Sardegna nor-occidentale). Bollettino della Società Sarda di Scienze Naturali, 5: 1-14.

Pereira, R. \& Cabral, M.C. 2005. Charophytes from the lower Aptian of Rio de Mouro (Lisbon region, Portugal), with the description of a new genus. Revista Española de Micropaleontologia, 37(1): 171-181.

Pereira, R., Feist, M. \& Azerêdo, A.C. 2003. New charophytes from the Upper Jurassic of the Lusitanian Basin (Portugal). Journal of Micropalaeontology, 22: 113-126.

Ramalho, M.M. 1971. Contribution à l'étude micropaléontologique et stratigraphique du Jurassique supérieur des environs de Lisbonne (Portugal). Memórias dos Serviços Geológicos de Portugal, 19: 218 pp.

Ramalho, M.M. \& Rey, J. 1975. État des connaissances actuelles sur le Jurassique terminal et Crétacé basal du Portugal. Mémoires du Bureau de Recherches Géologique et Minières, 86: 265-273.

Ramalho, M.M., Pais, J., Rey, J. et al. 1993. Notícia explicativa da Folha 34-A (Sintra) da Carta Geológica de Portugal à escala 1 : 50.000. Serviços Geológicos de Portugal, 77 pp.

Ramalho, M.M., Rey, J., Zbyzewsky, G., Matos Alves, C.A., Moitinho de Almeida, F., Costa, C. \& Kullberg, C. 1981. Noticia explicativa da Folha 34-C (Cascais) da Carta Geológica de Portugal à escala 1 : 50 000. Serviços Geológicos de Portugal, 87 pp.

Reid, C. \& Groves, J. 1916. Preliminary report on the Purbeck Characeae. Proceedings of the Royal Society of London, Series B, 89: 252-256.

Rey, J. 1972. Recherches géologiques sur le Crétacé inférieur de l'Estremadura (Portugal). Memórias dos Serviços Geológicos de Portugal, 21: 477 pp.
Rey, J. 1979. Le Crétacé inférieur de la marge Atlantique portugaise: biostratigraphie, organisation séquentielle, évolution paléogéographique. Ciências da Terra, 5: 97-120.

Rey, J. 1992. Les unités lithostratigraphiques du Crétacé inférieur de la région de Lisbonne. Comunicações dos Serviços Geológicos de Portugal, 78(2): 103-124.

Rey, J., Dinis, J.L., Callapez, P. \& Cunha, P.P. 2006. Da rotura continental à margem passiva. Composição e evolução do Cretácico de Portugal. Cadernos de Geologia de Portugal, Instituto Nacional de Engenharia, Tecnologia e Inovação, 77 pp.

Rey, J., Grambast, L., Oertli, H.J. \& Ramalho, M.M. 1968. Les couches du passage du Jurassique au Crétacé au nord du Tage (Portugal). Compte Rendu Sommaire de la Société Géologique de France, 5: $153-154$.

Ribeiro, A., Antunes, M.T., Ferreira, M.P. et al. 1979. Introduction à la géologie générale du Portugal. Serviços Geológicos de Portugal, $114 \mathrm{pp}$.

Riveline, J., Berger, J-P., Feist, M., Martín-Closas, C., Schudack, M. \& Soulié-Märsche, I. 1996. European Mesozoic-Cenozoic biozonation. Bulletin de la Société Géologique de France, 167(3): 453-468.

Schudack, M.E. 1986. Zur Nomenklatur der Gattungen Porochara MÄDLER 1955 (syn. Musacchiella FEIST \& GRAMBASTFESSARD 1984) und Feistiella n.gen. (Charophyta). Paläontologische Zeitschrift, 60: 21-27.

Schudack, M.E. 1989. Charophytenfloren aus den unterkretazischen Vertebraten-Fundschichten bei Galve und Uña (Ostspanien). Berliner geowissenschaftiche Abhandlungen, Reihe A: Geologie und Palaontologie 106: 409-443.

Schudack, M.E. 1993a. Die Charophyten in Oberjura und Unterkreide Westeuropas. Mit einer phylogenetischen Analyse der Gesamtgruppe. Berliner geowissenschaftliche Abhandlungen, Reihe A: Geologie und Paläontologie, 8: 1-209.

Schudack, M.E. 1993b. Möglichkeiten palökologischer Aussagen mit Hilfe von fossilen Charophyten. In Festschrift Prof. W. Krutzsch, 39-60. Museum fur Naturkunde, Berlin.

Schudack, M.E. 1996a. Charophyten des Kimmeridgium, Tithonium und Berrasium aus Bohrungen in Mecklenburg und Brandenburg (Nordostdeutschland). Hallesches Jahrbuch fur Geowissenschaften, Reihe B, 18: 153-170.

Schudack, M.E. 1996b. Die Charophyten des Niedersächischen Beckens (Oberjura-Berrasium): Lokalzonierung, überregionale Korrelation und Palökologie. Neues Jahrbuch fur Geologie und Paläontologie Abhandlungen, 200(1/2): 27-52.

Schudack, M.E. 1999. Some Charophytes from the Middle Dinosaur member of the Tendaguru formation (Upper Jurassic of Tanzania). Mitteilungen aus dem Museum fur Naturkunde in Berlin, Geowissenschaften, Reihe, 2: 201-205.

Shaikin, I.M. 1967. Charophytes fossiles des sédiments du Jurassique supérieur de la dépression Dniepr-Donets. In Algues fossiles d'U.R.S.S, 43-47. Nauka, Moscow.

Shaikin, I.M. 1976. New data on biostratigraphy of the Jurassic and Cretaceous deposits of the Fore-Dobrogean trough. Geologicheskiy Zhurnal, Kiev, 36(2): 77-86. [In Russian].

Soulié-Märsche, I. \& Joseph, C. 1991. Fiabilité des donnés morphométriques en micropaléontologie: exemple des charophytes. Geobios, Mémoire special, 13: 113-123.

Soulié-Märsche, I., Gemayel, P. \& Massieux, M. 1991. Étude de la variation populationnelle d'une charophyte de l'Éocène Pyrénéen par analyses multidimensionnelles. Geobios, 24(5): 537-548.

Wilson, R.C.L., Hiscott, R.N., Willis, M.G. \& Gradstein, F.M. 1989. The Lusitanian Basin of West-Central Portugal: Mesozoic and Tertiary Tectonic, Stratigraphic, and Subsidence History. In: Tankard, A.J. \& Balkwill, H.R. (Eds), Extensional Tectonics of the North Atlantic Margins, 341-361. American Association of Petroleum Geology, 46. 